\title{
Individual-and community-level determinants of neonatal mortality in the emerging regions of Ethiopia: a multilevel mixed-effect analysis
}

Getayeneh Antehunegn Tesema ${ }^{1 *}$ and Misganaw Gebrie Worku

\begin{abstract}
Background: Unlike infant and child mortality, neonatal mortality has declined steadily in Ethiopia. Despite the large-scale investment made by Ethiopia to improve the health of newborns and infants, it is among the regions with the highest burden of neonatal mortality. Although there are studies done on neonatal mortality in different areas of Ethiopia, as to our search of pieces of literature there is no study in Emerging regions of the country. Therefore, this study aimed to investigate the individual and community-level determinants of neonatal mortality in the Emerging regions of Ethiopia.

Methods: Using the 2016 Ethiopian Demographic and Health Survey (EDHS) data, secondary data analysis was done. A total weighted sample of 4238 live births in Emerging regions were included for the final analysis. A multilevel binary logistic regression was fitted to identify the significant determinants of neonatal mortality. The Intra-class Correlation Coefficient (ICC), Median Odds Ratio (MOR), Proportional Change in Variance (PCV) were used for assessing the clustering effect, and deviance for model comparison. Variables with a $p$-value $<0.2$ in the bivariable analysis were considered in the multivariable analysis. In the multivariable multilevel binary logistic regression analysis, Adjusted Odds Ratio (AOR) with 95\% Confidence Interval (CI) were reported to declare statistically significant determinants of neonatal mortality.

Results: The neonatal mortality rate in Emerging regions of Ethiopia was 34.9 per 1000 live births (95\% Cl: 29.8, 40.9). Being born to a mother who had no formal education ( $\mathrm{AOR}=1.79,95 \% \mathrm{Cl}: 1.12,2.88$ ), being born to a mother who did not participate in making health care decisions ( $\mathrm{AOR}=1.25,95 \% \mathrm{Cl}$ : 1.14, 1.79), and being twin birth $(A O R=6.85,95 \% \mathrm{Cl}: 3.69,12.70)$ were significantly associated with higher odds of neonatal mortality. On the other hand, being female ( $A O R=0.67,95 \% \mathrm{Cl}$ : 0.47, 0.95), having 1-3 Antenatal Care (ANC) visits ( $\mathrm{AOR}=0.34,95 \%$ $\mathrm{Cl}: 0.15,0.74)$, high community media exposure (AOR $=0.64,95 \% \mathrm{Cl}: 0.41,0.98)$, and preceding birth interval of two to 4 years ( $A O R=0.38,95 \% \mathrm{Cl}: 0.24,0.58)$ were significantly associated with lower odds of neonatal mortality.

(Continued on next page)
\end{abstract}

\footnotetext{
* Correspondence: getayenehantehunegn@gmail.com

'Department of Epidemiology and Biostatistics, Institute of Public Health, College of Medicine and Health Sciences, University of Gondar, Gondar, Ethiopia

Full list of author information is available at the end of the article
}

(c) The Author(s). 2021, corrected publication 2021. Open Access This article is licensed under a Creative Commons Attribution 4.0 International License, which permits use, sharing, adaptation, distribution and reproduction in any medium or format, as long as you give appropriate credit to the original author(s) and the source, provide a link to the Creative Commons licence, and indicate if changes were made. The images or other third party material in this article are included in the article's Creative Commons licence, unless indicated otherwise in a credit line to the material. If material is not included in the article's Creative Commons licence and your intended use is not permitted by statutory regulation or exceeds the permitted use, you will need to obtain permission directly from the copyright holder. To view a copy of this licence, visit http://creativecommons.org/ licenses/by/4.0/. The Creative Commons Public Domain Dedication waiver (http://creativecommons.org/publicdomain/zero/1. 0/) applies to the data made available in this article, unless otherwise stated in a credit line to the data. 
(Continued from previous page)

Conclusion: Neonatal mortality in Emerging regions of Ethiopia was unacceptably high. Maternal education, women's autonomy in making decisions for health care, sex of a child, type of birth, preceding birth interval, ANC visit, and community media exposure were found significant determinants of neonatal mortality. Therefore, empowering women in making health care decisions and increasing access to mass media play a major role in reducing the incidence of neonatal mortality in Emerging regions of Ethiopia.

Keywords: Ethiopia, Neonatal mortality, Emerging regions, Multilevel analysis

\section{Background}

Globally, under-five mortality significantly decreased from 12.7 million in 1990 to 6.3 million in 2015 with 2.6 million died during the neonatal period [1]. It accounting for $40 \%$ of under-five mortality [2]. Approximately 98\% of neonatal deaths occurred in low and middle-income countries [3, 4] and 39\% in sub-Saharan African (SSA) countries [5]. The neonatal mortality rate has varied across countries ranged from 20 per 1000 live births in high-income countries to 31 per 1000 live births in SSA [6]. It is far below to achieve the Sustainable Development Goal (SDG) target of reducing the neonatal mortality rate of 12 or less per 1000 live births by $2030[7,8]$.

Despite the substantial decrease in child and infant mortality, the decline in neonatal mortality is steady [9]. As in most African countries, Ethiopia is one of the countries with the highest burden of neonatal mortality [10]. In Ethiopia, though child and under-5 mortality has dramatically decreased in the last two decades, neonatal mortality has steadily decreased [11]. According to the Ethiopian Demographic and Health Surveys (EDHSs) report, under-five mortality decreased from 166 per 1000 live births to 67 per 1000 live births, and infant mortality decreased from 97 per 1000 births to 48 per 1000 births, while neonatal mortality decreased from 49 per 1000 live births to 29 per 1000 live births, which is lower than under-five and infant mortality [12-14].

Infectious diseases, malnutrition, and birth complications are identified as the leading causes of neonatal mortality $[2,4,15]$. Previous studies conducted on neonatal mortality showed that residence [16], parity [17], educational status [17], mode of delivery [18], ANC utilization [19], birth interval [20], place of delivery [21], maternal nutritional status [22], and maternal obstetric factors [23] were statistically significant determinants of neonatal mortality. Neonatal mortality has significantly reduced in Ethiopia in the last two decades. However, it is marginally higher in Somalia, Afar, Gambella, and Benishangul-Gumuz regions [13, 24]. This highlights Ethiopia should work further to reach the Every Newborn Action Plan (ENAP) set a national target of less than 10 per 1000 live births by 2035 [25].

Though there are studies conducted on neonatal mortality in different areas of Ethiopia [26-29], there is limited evidence on the individual-and community-level determinants of neonatal mortality in Emerging regions. Therefore, this study aimed to investigate the individual and community level determinants of neonatal mortality in Emerging regions of Ethiopia using multilevel logistic regression analysis. Identifying significant individual and community-level determinants of neonatal mortality is crucial to reduce the incidence of neonatal mortality in Emerging regions of Ethiopia.

\section{Methods}

\section{Study setting and design}

The study used the 2016 Ethiopian Demographic and Health Survey (EDHS) data, which was obtained using a community-based cross-sectional study design. The 2016 EDHS is the fourth survey conducted in every fiveyear interval in Ethiopia. There are nine regional states (Afar, Amhara, Benishangul-Gumuz, Gambella, Harari, Oromia, Somali, Southern Nations Nationalities and People's Region (SNNPR), and Tigray) and two city administrations (Addis Ababa and Dire Dawa) in Ethiopia. These regions are classified into three regions; emerging regions (Afar, Somali, Benishangul-Gumuz, and Gambella), developed regions (Amhara, Oromia, Harari, Southern Nations Nationalities and People's Region (SNNPR) and Tigray) and two city administrations (Addis Ababa and Dire Dawa) [30]. A total of 13.1 million people of Ethiopia are living in Somali, Afar, Benishangul-Gumuz, and Gambella regions [31]. These regions are characterized by scattered pastoralists and semi-pastoral populations with extreme poverty and limited access to health care.

\section{Data source and sampling procedure}

The data used for this study were retrieved from the most recent Ethiopian DHS survey (EDHS 2016). The EDHS is conducted every five-year using structured methodology and pretested validated standard tools to generate updated health and health-related indicators. The EDHS employs a multi-stage stratified cluster sampling technique to select the study subjects. In the first stage, a total of 645 Enumeration Areas (EAs) that represent the country were selected. In the second stage, systematic random sampling was employed and on average 
28 households per EAs were selected. For this study, neonates born in Emerging regions of Ethiopia within 5 years preceding the survey were included. A total of 4238 neonates were used for analysis. The overall data collection and the sampling procedure was presented in the full EDHS 2016 report [13].

\section{Study variables}

\section{Outcome variable}

The outcome variable for this study was neonatal death as reported by the mother, and it was defined as the death of a neonate within the first months of birth. This takes a binary outcome; such that neonatal death will be regarded as death $(1=$ if death occurs in the first month of life) or alive $(0=$ if the newborn alive in the first month of life).

\section{Independent variables}

The independent variable considered for this study were from two levels (at individual and community levels). At the individual, maternal age, marital status, religion, maternal education, paternal education, wealth index, maternal occupation, media exposure, maternal Body Mass Index (BMI)), number of ANC visit, the timing of first ANC visit, mode of delivery, preceding birth interval, place of delivery, women health care decision autonomy, size at birth, type of birth and birth order were included. At the community level, region, residence, community women education, community poverty, community media exposure, and distance to a health facility were considered. Community-level variables used in the analysis were from two sources; direct community-level variables that were used without any manipulation and aggregated community-level variables that were generated by aggregating individual-level variables at the cluster level.

Media exposure was measured from three variables such as reading the newspaper, listening to the radio, and watching television. These variables were merged and categorized as no "when there was no exposure to either of the three" and yes "when there was exposure to either of reading newspaper, listening radio and watching television". Women's health care decision making autonomy was assessed in EDHS, as a person decides on the respondent's own health care. Which was categorized as women participating in making their own health care decisions and didn't participate in making health care decisions (decides by their husband/partner). Birth weight was categorized as small, average, and large size at birth. Small size at birth is defined as birth weight less than $2500 \mathrm{~g}$ while birth weight greater than $4000 \mathrm{~g}$ is considered as large size at birth.

\section{Data collection procedure}

The research was performed based on the 2016 EDHS data by accessing the data from the official database of the MEASURE DHS program www.measuredhs.com. For the study, we used the Birth Record (BR) data set.

\section{Data management and analysis}

The variables were extracted from the BR dataset using STATA version 14 statistical software. The weighted data were used for analysis to adjust for unequal probability of selection and non-response. In EDHS, multistage stratified cluster sampling techniques were employed and the data were not flat. So, to draw valid inference and conclusion advanced statistical models such as hierarchical modelling, which consider independent variables measured at individual and community levels should be employed to consider the clustering effect/dependency. A two-level binary logistic regression model was employed to estimate the effect size of independent variables on neonatal mortality. Four models were fitted. The first model was the null model (a model without the explanatory variable), which was a model fitted to calculate the extent of cluster variability on neonatal mortality. It was assessed using the Likelihood Ratio test (LR), Intra-class Correlation Coefficient (ICC), Median Odds Ratio (MOR), and Proportional Change in Variance (PCV). The ICC is the proportion of total variance explained by the cluster variation [32].

$\mathrm{ICC}=\sigma^{2} /\left(\sigma^{2}+\pi^{2} / 3\right)$

Where $\partial^{2}$ indicates that cluster variance.

MOR is the median values of the odds ratio of the cluster at high risk and cluster at lower risk of neonatal mortality when randomly picking two neonates from two clusters (EAs) [33].

$$
\begin{aligned}
\mathrm{MOR} & =\exp (\sqrt{2 * \partial 2 * 0.6745}) \sim \mathrm{MOR} \\
& =\exp (0.95 * \partial)
\end{aligned}
$$

PCV is defined as the total variation of neonatal mortality explained by the final model (a model with individual-level factors and community-level variables) relative to the null model (a model without independent variables).

$$
\mathrm{PCV}=\operatorname{var}(\text { null model })-\operatorname{var} \text { full model }))
$$

Var (null model)

Model II (a multilevel model with individual-level variables); Model III (a multilevel model with communitylevel variables) and Model IV (a multilevel model adjusted with individual-and community-level variables) were fitted and a model comparison was made based on deviance. 
Table 1 Socio-demographic and economic characteristics of mothers, 2016

\begin{tabular}{|c|c|c|}
\hline Variables & $\begin{array}{l}\text { Frequency } \\
(N=4238)\end{array}$ & $\begin{array}{l}\text { Percentage } \\
\text { (\%) }\end{array}$ \\
\hline \multicolumn{3}{|l|}{ Maternal age (years) } \\
\hline$<20$ & 146 & 3.5 \\
\hline $20-34$ & 3082 & 72.7 \\
\hline $35^{+}$ & 1010 & 23.8 \\
\hline \multicolumn{3}{|c|}{ Maternal education status } \\
\hline No education & 3170 & 74.8 \\
\hline Primary & 764 & 18.0 \\
\hline Secondary and above & 304 & 7.2 \\
\hline \multicolumn{3}{|l|}{ Religion } \\
\hline Orthodox & 352 & 8.3 \\
\hline Muslim & 3068 & 72.4 \\
\hline Protestant & 697 & 16.5 \\
\hline Others & 121 & 2.9 \\
\hline \multicolumn{3}{|l|}{ Wealth status } \\
\hline Rich & 776 & 18.3 \\
\hline Medium & 303 & 7.2 \\
\hline Poor & 3159 & 74.5 \\
\hline \multicolumn{3}{|l|}{ Marital status } \\
\hline Never married & 9 & 0.2 \\
\hline Married & 3997 & 94.3 \\
\hline $\begin{array}{l}\text { Divorced/separated/ } \\
\text { widowed }\end{array}$ & 232 & 5.5 \\
\hline \multicolumn{3}{|c|}{ Women's occupation status } \\
\hline Not working & 2787 & 65.8 \\
\hline Working & 1451 & 34.2 \\
\hline \multicolumn{3}{|l|}{ Paternal education } \\
\hline No education & 2476 & 58.4 \\
\hline Primary & 800 & 18.9 \\
\hline Secondary and above & 962 & 22.7 \\
\hline \multicolumn{3}{|l|}{ Media exposure } \\
\hline No & 3397 & 80.2 \\
\hline Yes & 841 & 19.8 \\
\hline \multicolumn{3}{|l|}{ Maternal BMI } \\
\hline$<18.5 \mathrm{~kg} / \mathrm{m}^{2}$ & 1256 & 29.6 \\
\hline $18.5-24.9 \mathrm{~kg} / \mathrm{m}^{2}$ & 2450 & 57.8 \\
\hline$\geq 25 \mathrm{~kg} / \mathrm{m}^{2}$ & 532 & 12.6 \\
\hline
\end{tabular}

BMI Body Mass Index, $\mathrm{kg}$ Kilograms, $\mathrm{m}^{2}$ Meter Square

Both bivariable and multivariable analyses were done. In the bivariable two-level binary logistic regression analysis, variables with a $p$-value $\leq 0.2$ were considered in the multivariable analysis. The Adjusted Odds Ratio (AOR) with a 95\% Confidence Interval (CI) in the multivariable multilevel analysis were reported to declare the statistical significance and strength of association
Table 2 Obstetric and health service related characteristics of respondents

\begin{tabular}{lll}
\hline Variable & frequency & Percentage (\%) \\
\hline Place of delivery & & \\
Home & 2894 & 68.2 \\
Health facility & 1347 & 31.8 \\
Mode of delivery & & \\
Vaginal & 4118 & 97.2 \\
Caesarean section & 120 & 2.8
\end{tabular}

\section{Type of birth}

$\begin{array}{lll}\text { Single } & 4134 & 97.6\end{array}$

$\begin{array}{lll}\text { Twin } & 104 & 2.4\end{array}$

\section{Birth order}

First birth $\quad 769$

$\begin{array}{lll}2-4 & 1848 & 43.6\end{array}$

$\begin{array}{lll}\geq 5 & 1621 & 38.2\end{array}$

Preceding birth interval (in years)$$
<2
$$

$>4$

1251

Timing of first ANC visit

No ANC visit

$3177 \quad 74.9$

First trimester

354

74.9

Second trimester

672

Third trimester

Number of ANC visit

No
$1-3$
$\geq 4$

\section{7}

0.9

Size of neonate at birth

$\begin{array}{lll}\text { Small } & 1031 & 24.3 \\ \text { Average } & 1488 & 35.1 \\ \text { Large } & 1719 & 40.6\end{array}$

Women participating in making health care decisions

$\begin{array}{lll}\text { No } & 1264 & 29.8 \\ \text { Yes } & 2974 & 70.2\end{array}$

Sex of child

\begin{tabular}{lll} 
Male & 2223 & 52.5 \\
Female & 2015 & 47.5 \\
\hline
\end{tabular}

ANC Antenatal Care

between neonatal mortality and independent variables. By doing the pseudo linear regression analysis, the multi-collinearity was checked and the mean VIF was less than 5. 
Table 3 Community level characteristics of respondents, 2016

\begin{tabular}{lll}
\hline Variable & Frequency & Percentage (\%) \\
\hline Region & 1097 & 25.9 \\
Afar & 890 & 21.0 \\
Benishangul-Gumuz & 724 & 17.1 \\
Gambella & 1527 & 36.0 \\
$\quad$ Somali & & \\
Residence & 3605 & 85.1 \\
$\quad$ Rural & 633 & 14.9 \\
$\quad$ Urban & & \\
Distance to health facility & 2472 & 58.3 \\
Big problem & 1766 & 41.7 \\
Not a big problem & & \\
Community poverty & 1879 & 44.3 \\
Low & 2359 & 55.7 \\
High & & \\
Community women education & & 57.3 \\
Low & 2429 & 42.7 \\
High & 1812 & 53.6 \\
Community media exposure & & \\
Low & 2273 & 1965 \\
High & & \\
\hline
\end{tabular}

\section{Results}

Socio-demographic and economic characteristics of the mothers

A total weighted sample of 4238 neonates were used for this study. The majority (74.8\%) of neonates were born to mothers with no formal education and 3997 (94.3\%) of neonate's mother were married. Of the total neonates, 3397 (80.2\%) of their mothers did not have media exposure and $3082(72.7 \%)$ of neonates were born to mothers aged 20-34 years. The majority $(72.4 \%)$ of neonate's mother was Muslim religion followers (Table 1).

\section{Child and maternal obstetric related characteristics}

From a total of 4238 neonates, $52.5 \%$ were males and $68.2 \%$ were born at home. About $13.1 \%$ of the mothers had 1-3 ANC visits during their pregnancy and 2.8\% were delivered through caesarean section. About 2.4\% were twin births and $40.6 \%$ were large size at birth. Nearly three-fourths $(70.2 \%)$ of the mothers were participated in making their own health care decisions (Table 2).

\section{Community-level characteristics of the mothers}

About $85.1 \%$ of neonate's mothers were from rural residents and $36.0 \%$ were in the Somali region. The majority (55.7\%) of their mother was from a community with high poverty and $58.3 \%$ of the mothers reported perceived distance to visit health facilities as a big problem (Table 3).

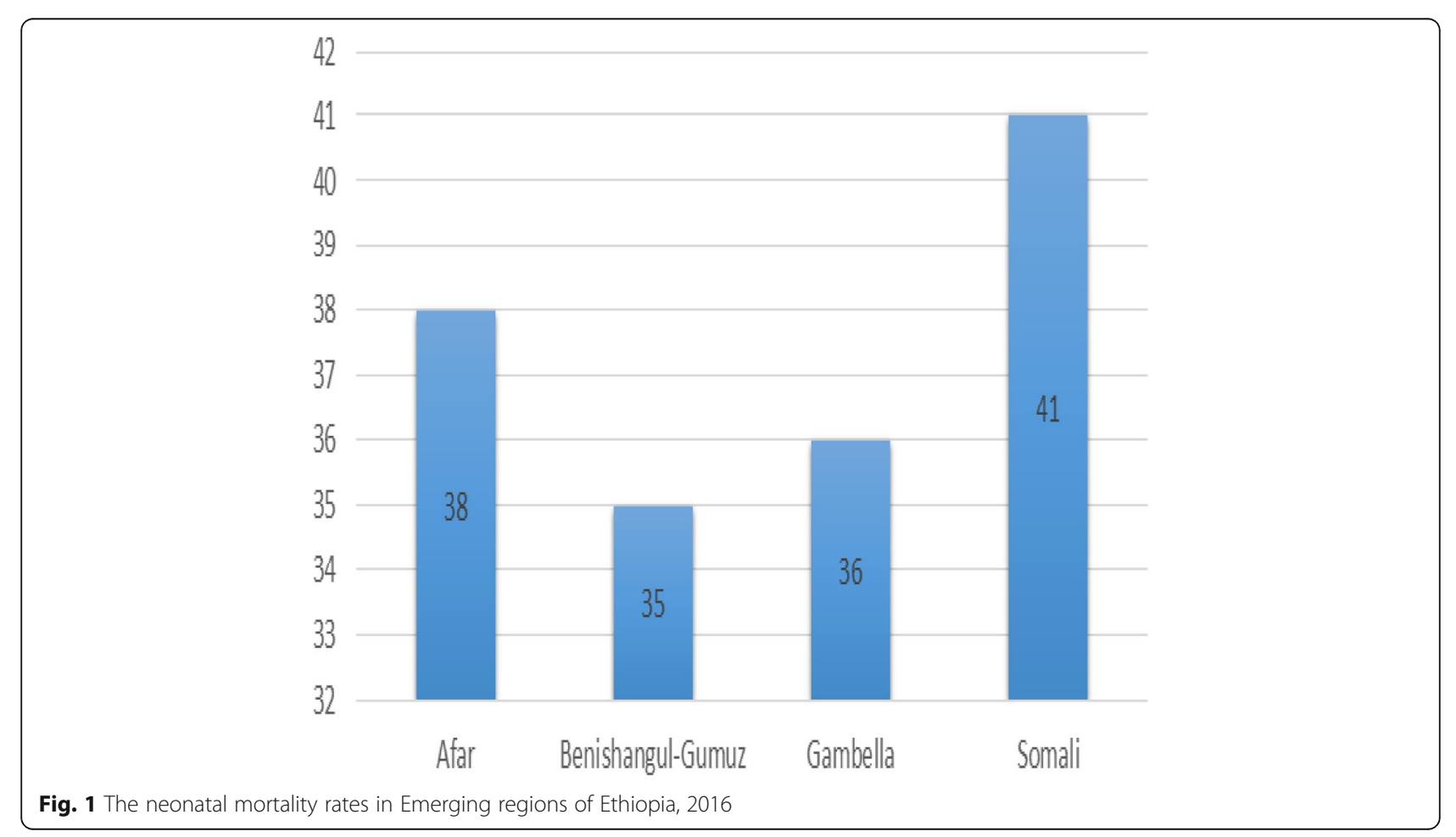


Table 4 Neonatal mortality rate by respondent characteristics,

\begin{tabular}{|c|c|}
\hline Variable & Neonatal mortality rate \\
\hline \multicolumn{2}{|l|}{ Residence } \\
\hline Urban & 14.2 \\
\hline Rural & 38.6 \\
\hline \multicolumn{2}{|l|}{ Wealth status } \\
\hline Poor & 39.6 \\
\hline Medium & 26.4 \\
\hline Rich & 19.3 \\
\hline \multicolumn{2}{|l|}{ Media exposure } \\
\hline No & 37.7 \\
\hline Yes & 23.8 \\
\hline \multicolumn{2}{|l|}{ Maternal age } \\
\hline$<20$ & 47.9 \\
\hline $20-34$ & 30.8 \\
\hline $35^{+}$ & 45.5 \\
\hline \multicolumn{2}{|l|}{ Place of delivery } \\
\hline Home & 38.4 \\
\hline Health facility & 27.5 \\
\hline \multicolumn{2}{|l|}{ Type of birth } \\
\hline Single & 31.7 \\
\hline Twin & 163.5 \\
\hline \multicolumn{2}{|l|}{ Size at birth } \\
\hline Small & 36.6 \\
\hline Average & 31.6 \\
\hline Large & 36.9 \\
\hline \multicolumn{2}{|l|}{ Maternal education } \\
\hline No education & 34.4 \\
\hline Primary & 40.6 \\
\hline Secondary and above & 26.3 \\
\hline
\end{tabular}

\section{Neonatal mortality rate by respondent characteristics}

The neonatal mortality rate in Emerging regions of Ethiopia was 34.9 (95\% CI: 29.8, 40.9) per 1000 live births, which was highest in the Somali region (41 per 1000 live births) and lowest in the Benishangul region (35 per 1000 live births) (Fig. 1). The neonatal mortality rate among rural residents was 38.6 per 1000 live births (Table 4).

\section{Determinants of neonatal mortality Model comparison}

The final model was the best-fitted model since it had the lowest deviance value. The ICC was $13.5 \%$ in the null model indicated that $13.5 \%$ of the total variability of neonatal mortality was due to differences between clusters/EA, with the remaining unexplained $86.5 \%$ was attributable to individual differences. Moreover, the MOR was 1.98 in the null model which indicates that there was variation between clusters, if we randomly select neonate from two different clusters, neonate at the cluster with a higher risk of neonatal mortality had 1.98 times higher odds of neonatal mortality as compared with neonate at cluster with a lower risk of neonatal mortality. PCV for the final model was $37.3 \%$, indicated that $37.3 \%$ of the variability in neonatal mortality was explained by the full model (Table 5).

In the multivariable multilevel analysis; maternal education, women who didn't participate in making their own health care decisions, twin births, preceding birth interval, number of ANC visits, community media exposure, and sex of child were significantly associated with neonatal mortality. The odds of neonatal mortality among live births born to mothers who didn't attend formal education had $1.79(\mathrm{AOR}=1.79,95 \% \mathrm{CI}$ : 1.12 , 2.88) times higher than live births born to mothers who attained secondary education and above. The odds of neonatal mortality among female births were decreased by $33 \%(\mathrm{AOR}=0.67,95 \% \mathrm{CI}: 0.47,0.95)$ compared to male births. Being born to mothers who didn't participate in making their own health care decisions were 1.25 ( $\mathrm{AOR}=1.25,95 \% \mathrm{CI}: 1.14,1.79)$ times higher odds of neonatal mortality than births whose mother who participated in making health care decisions. The odds of neonatal mortality among twin births were 6.85 (AOR = $6.85,95 \%$ CI: $3.69,12.70)$ times higher compared to singletons. Furthermore, the odds of neonatal mortality among neonates in the community that had high media exposure were decreased by $36 \%$ (AOR $=0.64,95 \% \mathrm{CI}$ : $0.41,0.98$ ) compared to neonates in the community with low media exposure. The odds of neonatal death for neonates with preceding birth interval 2 to 4 years were decreased by $62 \% \quad(\mathrm{AOR}=0.38,95 \% \mathrm{CI}: 0.24,0.58)$ compared to neonates with preceding birth interval less than 2 years. The odds of neonatal mortality among children born to mothers who had 1-3 ANC visits during pregnancy were decreased by $66 \%(\mathrm{AOR}=0.34,95 \% \mathrm{CI}$ : $0.15,0.74$ ) than a child born to a mother who didn't have ANC visit during pregnancy (Table 5).

\section{Discussion}

Thousands of newborns die each year from preventable causes such as infectious diseases, malnutrition, and accidents, despite impressive success in reducing neonatal, infant, and child mortality in Ethiopia [34]. Neonatal mortality is the most sensitive indicator of limited health care access such as institutional delivery, vaccination, medical treatment of diseases, nutrition, and hygiene $[35,36]$.

This study found that the neonatal mortality rate in emerging regions of Ethiopia was 34.9 [95\% CI: 29.8, 40.9] per 1000 live births. It was consistent with studies reported in the Jimma zone [26], and Nigeria [37]. However, it was higher than the 2016 EDHS report [13], and 
Table 5 Multivariable multilevel logistic regression analysis of neonatal mortality in emerging regions of Ethiopia, 2016

\begin{tabular}{|c|c|c|c|c|}
\hline Variable & $\begin{array}{l}\text { Null } \\
\text { model }\end{array}$ & $\begin{array}{l}\text { Model } 1 \text { (individual level } \\
\text { factors) }\end{array}$ & $\begin{array}{l}\text { Model } 2 \text { (Community level } \\
\text { factors) }\end{array}$ & $\begin{array}{l}\text { Model } 4 \text { (model with individual and community } \\
\text { level factors) }\end{array}$ \\
\hline \multicolumn{5}{|l|}{ Sex of neonate } \\
\hline Male & & 1 & & 1 \\
\hline Female & & $0.67[0.47,0.94]$ & & $0.67[0.47,0.94]^{a}$ \\
\hline \multicolumn{5}{|l|}{ Wealth index } \\
\hline Rich & & 1 & & 1 \\
\hline Middle & & $1.11[0.44,2.80]$ & & $0.87[0.33,2.27]$ \\
\hline Poor & & $1.73[0.91,3.27]$ & & $1.22[0.58,2.55]$ \\
\hline \multicolumn{5}{|l|}{ Birth order } \\
\hline First birth & & 1 & & 1 \\
\hline $2-4$ & & $0.55[0.28,1.07]$ & & $0.62[0.32,1.21]$ \\
\hline$\geq 5$ & & $0.73[0.36,1.48]$ & & $0.82[0.40,1.66]$ \\
\hline \multicolumn{5}{|l|}{ Type of birth } \\
\hline Single & & 1 & & 1 \\
\hline Twin & & $7.14[3.84,13.29]$ & & $6.85[3.69,12.70]^{a}$ \\
\hline \multicolumn{5}{|c|}{ Preceding birth interval } \\
\hline$<2$ year & & 1 & & 1 \\
\hline 2-4 year & & $0.36[0.23,0.56]$ & & $0.38[0.24,0.58]^{\mathrm{a}}$ \\
\hline$>4$ year & & $0.58[0.32,1.04]$ & & $0.64[0.35,1.17]$ \\
\hline \multicolumn{5}{|c|}{ Women participating in making their own heath care decisions } \\
\hline Yes & & 1 & & 1 \\
\hline No & & $1.24[1.12,1.79]$ & & $1.25[1.14,1.79]^{\mathrm{a}}$ \\
\hline \multicolumn{5}{|l|}{ Media exposure } \\
\hline No & & 1 & & 1 \\
\hline Yes & & $0.73[0.42,1.25]$ & & $0.97[0.55,1.73]$ \\
\hline \multicolumn{5}{|c|}{ Number of ANC visits } \\
\hline No visit & & 1 & & 1 \\
\hline $1-3$ & & $0.30(0.14,0.65)$ & & $0.34(0.15,0.74)^{\mathrm{a}}$ \\
\hline$\geq 4$ & & $0.44(0.22,0.88)$ & & $0.55(0.26,1.15)$ \\
\hline \multicolumn{5}{|l|}{ Place of delivery } \\
\hline Home & & 1 & & 1 \\
\hline Health facility & & $0.77[0.51,1.16]$ & & $0.81[0.54,1.23]$ \\
\hline \multicolumn{5}{|l|}{ Maternal education } \\
\hline No education & & $1.66[1.04,2.65]$ & & $1.79[1.12,2.88]^{a}$ \\
\hline Primary & & $1.21[0.53,2.78]$ & & $1.50[0.65,3.46]$ \\
\hline $\begin{array}{l}\text { Secondary and } \\
\text { higher }\end{array}$ & & 1 & & 1 \\
\hline \multicolumn{5}{|l|}{ Residence } \\
\hline Urban & & & 1 & 1 \\
\hline Rural & & & $2.04[0.91,4.54]$ & $1.82[0.75,4.38]$ \\
\hline \multicolumn{5}{|c|}{ Distance to health facility } \\
\hline Not a big problem & & & 1 & 1 \\
\hline Big problem & & & $1.21[0.83,1.78]$ & $1.16[0.78,1.72]$ \\
\hline \multicolumn{5}{|l|}{ Community poverty } \\
\hline Low & & & 1 & 1 \\
\hline
\end{tabular}


Table 5 Multivariable multilevel logistic regression analysis of neonatal mortality in emerging regions of Ethiopia, 2016 (Continued)

\begin{tabular}{lllll}
\hline Variable & $\begin{array}{l}\text { Null } \\
\text { model }\end{array}$ & $\begin{array}{l}\text { Model 1 (individual level } \\
\text { factors) }\end{array}$ & $\begin{array}{l}\text { Model 2 (Community level } \\
\text { factors) }\end{array}$ & $\begin{array}{l}\text { Model 4 (model with individual and community } \\
\text { level factors) }\end{array}$ \\
\hline High & & & $1.04[0.67,1.62]$ & $0.85[0.52,1.39]$ \\
Community media exposure & & 1 & 1 \\
No & & $0.63[0.41,0.97]$ & $0.64[0.41,0.98]^{\mathrm{a}}$ \\
Yes & & & \\
Random effect & & 0.41 & 0.37 & 0.32 \\
Community level & 0.51 & & -627.50 & -593.68 \\
variance & & & 1255.0 & 1187.36 \\
Log likelihood & -635.27 & -597.78 & $10.0 \%$ & $8.9 \%$ \\
Deviance & 1270.54 & 1195.56 & 1.78 & 1.72 \\
ICC & $13.5 \%$ & $11.0 \%$ & $27.5 \%$ & $37.3 \%$ \\
MOR & 1.98 & 1.84 & $19.6 \%$ & ref
\end{tabular}

${ }^{a}$ ICC Intra-class Correlation Coefficient, MOR Median Odds Ratio, PCV Proportional Change in Variance

Afghanistan [38]. The possible explanation could be due to the present study was undertaken in Emerging regions (Somali, Afar, Gambella, and Benishangul-Gumuz) of Ethiopia where maternal and child health care services are relatively low and economically disadvantaged in contrast to other regions [39]. Furthermore, lower vaccine coverage reduced access to healthcare, poorly urbanized, and a comparatively high incidence of childhood infectious diseases such as malaria, and acute respiratory tract infections are found in Emerging regions compared to the other regions of the country $[40,41]$.

In the multilevel analysis; maternal education, preceding birth interval, type of birth, sex of neonate, community media exposure, number of ANC visits, and women participation in making health care decisions were significantly associated with neonatal mortality. A neonate born to mothers who do not have formal education had higher odds of neonatal mortality than a neonate born to mothers who attained secondary education and above. It is in line with studies reported in Sudan [42], Bangladesh [22], and Nigeria [16]. This may be because uneducated mothers may not have access to health information and less likely to visit maternal health care such as institutional delivery, ANC, and PNC [43, 44]. Another reason is uneducated mothers are reluctant to pursue childhood vaccination $[45,46]$ and more likely to practice prelacteal feeding [47], this could increase the risk of neonatal mortality. Besides, maternal education could result in good childhood feeding practices and have an improved awareness of common childhood disease preventive approaches that play a significant role in increasing newborn survival $[48,49]$.

In this study, being twin birth was a significant predictor of neonatal mortality. Twin births had higher odds of death in the first month of birth than singletons.
It is consistent with the study finding in Ghana [17]. This could be since twin births are at higher risk of preterm delivery and fetal growth restriction and this could increase their risk of hypothermia, sepsis, and hypoglycemia that might increase the risk of neonatal mortality [50]. Neonates born within the preceding birth interval of 2 to 4 years had lower odds of dying within the neonatal period than those having a preceding birth interval less than 2 years. It was consistent with prior studies conducted in India [51], Afghanistan [38], and Indonesia [52]. The possible justification might be due to the reason that optimal birth spacing is vital for the health of the mother and newborn. The interbirth interval of 2 to 4 years could result in good pregnancy outcomes as women restore their nutritional and physiological loss from a previous birth, this could decrease their incidence of neonatal mortality.

Births to women who did not participate in making health care decisions had higher odds of neonatal death. This was in line with a study conducted in Bangladesh [53], it might be due to the reason that women who have participated in making health care decisions are more likely to use antenatal care service, gave birth at the health facility, and have a postnatal checkup in the early neonatal period, this could help to early identify danger signs of pregnancy and neonates and to seek medical treatment $[54,55]$.

The odds of neonatal mortality among female neonates were lower than male neonates. This was consistent with studies reported in Indonesia [52], and Nigeria [37]. This could be due to the sex differences in genetic and biological makeup, with males being biologically weaker and more susceptible to diseases and mortality [56]. Besides, the difference in mortality might be attributed to the different protein and gene expression variation in the placenta [57]. 
This study found that community media exposure was a significant predictor of neonatal mortality. Newborns from the community with high media exposure had decreased odds of death in the neonatal period than neonates from the community with low media exposure. This is in line with the study done in Bangladesh [58], the possible explanation might be the reason that mothers who have media exposure had better awareness of ANC utilization, institutional delivery, and childhood illness [59].

Newborns born to mothers who had 1-3 ANC visits during pregnancy had lower odds of neonatal mortality than newborns born to mothers who did not have ANC visits during pregnancy. It was consistent with studies in Kenya [60] and India [61]. This might be because a pregnant mother who had antenatal care visits receives health care such as iron, deworming, folic acid, and tetanus immunizations, this could decrease the risk of neonatal mortality. Besides, ANC creates an opportunity for mothers and newborns to receive different interventions such as anti-D, childhood vaccinations, and nutritional supplementation.

The strength of this study was the use of multilevel modelling taking into account the clustering effect in EDHS to draw valid inferences and conclusions. This study had limitations. As this stud was a cross-sectional study, it shares the limitations of cross-sectional study design. Besides, variables such as infectious diseases, sepsis, congenital anomalies, transplacental infections, HIV status, and medication use which are considered as the most common cause of neonatal mortality were not included in this study since it was not collected in EDHS 2016.

\section{Conclusion}

Neonatal mortality in emerging regions of Ethiopia remains a major public health concern. Maternal education, women's participation in health care decision making, sex of the child, type of birth, preceding birth interval, number of ANC visits, and community media exposure were significantly associated with neonatal mortality. Therefore, empowering women in education and their autonomy in making health care decisions as well as improving access to media plays a significant role in reducing neonatal mortality in emerging regions of Ethiopia. The government should scale up maternal and child health services in these regions to reduce neonatal mortality at the national level.

\footnotetext{
Abbreviations

ANC: Antenatal Care; AOR: Adjusted Odds Ratio, ARR; BMI: Body Mass Index Cl: Confidence Interval; COR: Crude Odds Ratio; CSA: Central Statistical Agency; DHS: Demographic Health Survey; EA: Enumeration Area; EDHS: Ethiopian Demographic Health Survey; ICC: Intra-cluster Correlation Coefficient; LLR: Log-likelihood Ratio; LR: Likelihood Ratio; MOR: Median Odds Ratio; PCV: Proportional Change in Variance; PHC: Population and Housing
}

census; SNNPRs: Southern Nations and Nationality People Regional state; WHO: World Health Organization

\section{Acknowledgments}

We would like to thank the measure DHS program for providing the data set.

\section{Authors' contributions}

Conceptualization: GAT and MGW, Data curation: GAT and MGW, Investigation: GAT and MGW, Methodology: GAT and MGW, Resources: GAT and MGW, Software: GAT and MGW, Supervision: GAT, Validation: GAT, Visualization: GAT and MGW, Writing: GAT and MGW, Writing - review and editing: GAT and MGW. All the authors read and approve the manuscript.

\section{Funding}

No funding was obtained for this study.

\section{Availability of data and materials}

Data is available online and you can access it from www.measuredhs.com.

\section{Ethics approval and consent to participate}

The EDHS data is available to the general public by request in different formats from the Measure DHS website http://www.measuredhs.com. We submitted a request to the Measure DHS by briefly stating the objectives of this analysis and thereafter received permission to download the maternal and children's dataset in STATA format.

\section{Consent for publication}

Not applicable.

\section{Competing interests \\ Authors declare that they have no conflict of interest.}

\section{Author details}

${ }^{1}$ Department of Epidemiology and Biostatistics, Institute of Public Health, College of Medicine and Health Sciences, University of Gondar, Gondar, Ethiopia. ${ }^{2}$ Department of Human Anatomy, College of Medicine and Health Sciences, University of Gondar, Gondar, Ethiopia.

Received: 23 March 2020 Accepted: 16 December 2020

Published online: 06 January 2021

\section{References}

1. Vakili R, Emami Moghadam Z, Khademi G, Vakili S, Saeidi M. Child mortality at different world regions: a comparison review. Int J Pediatr. 2015;3(4.2): 809-16

2. Liu L, Oza S, Hogan D, Perin J, Rudan I, Lawn JE, et al. Global, regional, and national causes of child mortality in 2000-13, with projections to inform post-2015 priorities: an updated systematic analysis. Lancet. 2015;385(9966): 430-40.

3. Saleem S, McClure EM, Goudar SS, Patel A, Esamai F, Garces A, et al. A prospective study of maternal, fetal and neonatal deaths in low-and middle-income countries. Bull World Health Organ. 2014;92:605-12.

4. Smith ER, Shankar AH, Wu LS, Aboud S, Adu-Afarwuah S, Ali H, et al. Modifiers of the effect of maternal multiple micronutrient supplementation on stillbirth, birth outcomes, and infant mortality: a meta-analysis of individual patient data from 17 randomised trials in low-income and middle-income countries. Lancet Glob Health. 2017:5(11):e1090-e100.

5. Moyer CA, Dako-Gyeke P, Adanu RM. Facility-based delivery and maternal and early neonatal mortality in sub-Saharan Africa: a regional review of the literature. Afr J Reprod Health. 2013;17(3):30-43.

6. Lawn JE, Blencowe $H$, Oza S, You D, Lee AC, Waiswa P, et al. Every newborn: progress, priorities, and potential beyond survival. Lancet. 2014;384(9938): 189-205.

7. Kc A, Jha AK, Shrestha MP, Zhou H, Gurung A, Thapa J, et al. Trends for neonatal deaths in Nepal (2001-2016) to project progress towards the SDG target in 2030, and risk factor analyses to focus action. Matern Child Health J. 2020;24(1):5-14.

8. Puthenkalam JJ. Sustainable Development Goals as New Framework for Development From MDGs to SDGs. 上智経済論集. 2016;61(1):1-18. 
9. Wang $H$, Liddell CA, Coates MM, Mooney MD, Levitz CE, Schumacher AE, et al. Global, regional, and national levels of neonatal, infant, and under-5 mortality during 1990-2013: a systematic analysis for the global burden of disease study 2013. Lancet. 2014;384(9947):957-79.

10. Golding N, Burstein R, Longbottom J, Browne AJ, Fullman N, OsgoodZimmerman A, et al. Mapping under-5 and neonatal mortality in Africa, 2000-15: a baseline analysis for the sustainable development goals. Lancet. 2017;390(10108):2171-82.

11. Mekonnen Y, Tensou B, Telake DS, Degefie T, Bekele A. Neonatal mortality in Ethiopia: trends and determinants. BMC Public Health. 2013;13(1):483.

12. Iff C. Ethiopian demographic health survey 2011. Addis Ababa and Calverton: Central Statistical Agency (Ethiopia) and ICF International; 2012. p. 17-27.

13. ICF CSACEa. Ethiopia Demographic and Health Survey 2016. Addis Ababa, and Rockville: CSA and ICF; 2016.

14. macro CsAEaO. Ethiopian Demographic and Health survey 2005. Addis Ababa Calverton: CSA and ORC macro; 2005

15. Black RE, Cousens S, Johnson HL, Lawn JE, Rudan I, Bassani DG, et al. Global, regional, and national causes of child mortality in 2008: a systematic analysis. Lancet. 2010;375(9730):1969-87.

16. Ezeh OK, Agho KE, Dibley MJ, Hall J, Page AN. Determinants of neonatal mortality in Nigeria: evidence from the 2008 demographic and health survey. BMC Public Health. 2014;14(1):521.

17. Kayode GA, Ansah E, Agyepong IA, Amoakoh-Coleman M, Grobbee DE, Klipstein-Grobusch K. Individual and community determinants of neonatal mortality in Ghana: a multilevel analysis. BMC Pregnancy Childbirth. 2014; 14(1):165.

18. Walsh CA, Robson M, McAuliffe FM. Mode of delivery at term and adverse neonatal outcomes. Obstet Gynecol. 2013;121(1):122-8

19. Corman H, Grossman M. Determinants of neonatal mortality rates in the US: a reduced form model. J Health Econ. 1985;4(3):213-36.

20. Kolola T, Ekubay M, Tesfa E, Morka W. Determinants of neonatal mortality in north Shoa zone, Amhara regional state, Ethiopia. PloS One. 2016;11(10): e0164472.

21. Ajaari J, Masanja H, Weiner R, Abokyi SA, Owusu-Agyei S. Impact of place of delivery on neonatal mortality in rural Tanzania. Int J MCH AIDS. 2012;1(1): 49.

22. Kamal SM. Maternal education as a determinant of neonatal mortality in Bangladesh. J Health Manag. 2012;14(3):269-81.

23. Abdullah A, Hort K, Butu Y, Simpson L. Risk factors associated with neonatal deaths: a matched case-control study in Indonesia. Glob Health Action. 2016;9(1):30445

24. Negera A, Abelti G, Bogale T, Gebreselassie T, Pearson R. An analysis of the trends, differentials and key proximate determinants of infant and underfive mortality in Ethiopia. Calverton: ICF International; 2013.

25. Walker N, Yenokyan G, Friberg IK, Bryce J. Patterns in coverage of maternal, newborn, and child health interventions: projections of neonatal and under5 mortality to 2035. Lancet. 2013;382(9897):1029-38.

26. Debelew GT, Afework MF, Yalew AW. Determinants and causes of neonatal mortality in Jimma zone, southwest Ethiopia: a multilevel analysis of prospective follow up study. PLoS One. 2014;9(9):e107184.

27. Kolola T, Ekubay M, Tesfa E, Morka W. Determinants of neonatal mortality in North Shoa Zone, Amhara regional state, Ethiopia. PLoS One. 2016;11(10): e0164472.

28. Yirgu R, Molla M, Sibley L. Determinants of neonatal mortality in rural Northern Ethiopia: A population based nested case control study. PLoS One. 2017;12(4):e0172875-e

29. Wolde HF, Gonete KA, Akalu TY, Baraki AG, Lakew AM. Factors affecting neonatal mortality in the general population: evidence from the 2016 Ethiopian demographic and health survey (EDHS) — multilevel analysis. BMC Res Notes. 2019;12(1):610

30. UNCDF:. Emerging Regions Development Programme (ERDP): Programme Document. www.uncdf.org/download/file/erdp54573prodoc0.pdf Accessed 16 Dec 2019.

31. Ababa A. Demographics of Ethiopia; 2020.

32. Rodriguez G, Elo I. Intra-class correlation in random-effects models for binary data. Stata J. 2003;3(1):32-46

33. Merlo J, Chaix B, Ohlsson H, Beckman A, Johnell K, Hjerpe P, et al. A brief conceptual tutorial of multilevel analysis in social epidemiology: using measures of clustering in multilevel logistic regression to investigate contextual phenomena. J Epidemiol Community Health. 2006;60(4):290-7.
34. Lawn JE, Kerber K, Enweronu-Laryea C, Cousens S, editors. 3.6 million neonatal deaths - what is progressing and what is not? Seminars in perinatology: Elsevier; 2010.

35. Memon ZA, Khan GN, Soofi SB, Baig IY, Bhutta ZA. Impact of a communitybased perinatal and newborn preventive care package on perinatal and neonatal mortality in a remote mountainous district in northern Pakistan. BMC Pregnancy Childbirth. 2015;15(1):106

36. Dickson KE, Simen-Kapeu A, Kinney MV, Huicho L, Vesel L, Lackritz E, et al. Every newborn: health-systems bottlenecks and strategies to accelerate scale-up in countries. Lancet. 2014;384(9941):438-54.

37. Adewuyi E, Zhao Y, Lamichhane R. Socioeconomic, bio-demographic and health/behavioral determinants of neonatal mortality in Nigeria: a multilevel analysis of 2013 demographic and health survey. Int J Contemp Pediatr. 2016;3(2):311-23.

38. Al Kibria GM, Burrowes V, Choudhury A, Sharmeen A, Ghosh S, Mahmud A, et al. Determinants of early neonatal mortality in Afghanistan: an analysis of the demographic and health survey 2015. Glob Health. 2018;14(1):47.

39. Seide WM. The Nuer pastoralists: between large scale agriculture and villagization: a case study of the Lare District in the Gambella Region of Ethiopia: Nordiska Afrikainstitutet; 2017.

40. Admassie A, Abebaw D. Rural poverty and marginalization in Ethiopia: a review of development interventions. Marginality. 2014:269.

41. Woldesenbet PW. Provision of and participation in primary education in the pastoralist regions of Afar and Somali of Ethiopia; 2015.

42. Bashir AO, Ibrahim GH, Bashier IA, Adam I. Neonatal mortality in Sudan: analysis of the Sudan household survey, 2010. BMC Public Health. 2013:13(1):287.

43. Tsegay Y, Gebrehiwot T, Goicolea I, Edin K, Lemma H, San SM. Determinants of antenatal and delivery care utilization in Tigray region, Ethiopia: a crosssectional study. Int J Equity Health. 2013;12(1):30.

44. Shiferaw S, Spigt M, Godefrooij M, Melkamu Y, Tekie M. Why do women prefer home births in Ethiopia? BMC Pregnancy Childbirth. 2013;13(1):5.

45. Siddiqi N, Siddiqi AA, Nisar N, Khan A. Mothers' knowledge about EPI and its relation with age-appropriate vaccination of infants in peri-urban Karachi. J Pak Med Assoc. 2010;60(11):940.

46. Bofarraj MA. Knowledge, attitude and practices of mothers regarding immunization of infants and preschool children at Al-Beida City, Libya 2008. Egypt J Pediatr Allergy Immunol (The). 2011;9(1).

47. Sefene A, Birhanu D, Awoke W, Taye T. Determinants of exclusive breastfeeding practice among mothers of children age less than 6 month in Bahir Dar city administration, Northwest Ethiopia; a community based cross-sectional survey. Sci J Clin Med. 2013;2(6):153-9.

48. Campbell OM, Graham WJ. Group LMSSs. Strategies for reducing maternal mortality: getting on with what works. Lancet. 2006;368(9543):1284-99.

49. Haines A, Sanders D, Lehmann U, Rowe AK, Lawn JE, Jan S, et al. Achieving child survival goals: potential contribution of community health workers. Lancet. 2007;369(9579):2121-31.

50. Marchant T, Willey B, Katz J, Clarke S, Kariuki S, Ter Kuile F, et al. Neonatal mortality risk associated with preterm birth in East Africa, adjusted by weight for gestational age: individual participant level meta-analysis. PLoS Med. 2012;9(8):e1001292.

51. Bhalotra S, Van Soest A. Birth-spacing, fertility and neonatal mortality in India: dynamics, frailty, and fecundity. J Econ. 2008;143(2):274-90.

52. Titaley CR, Dibley MJ, Agho K, Roberts CL, Hall J. Determinants of neonatal mortality in Indonesia. BMC Public Health. 2008;8(1):232.

53. Hossain MB, Phillips JF, Pence B. The effect of women's status on infant and child mortality in four rural areas of Bangladesh. J Biosoc Sci. 2007;39(3):355.

54. Mahapatro SR. Utilization of maternal and child health care services in India: does women s autonomy matter? 2012

55. Dairo M, Owoyokun K. Factors affecting the utilization of antenatal care services in Ibadan, Nigeria. Benin J Postgrad Med. 2010;12(1).

56. Friedrich $L$, Stein RT, Pitrez PM, Corso AL, Jones $M H$. Reduced lung function in healthy preterm infants in the first months of life. Am J Respir Crit Care Med. 2006;173(4):442-7.

57. Quiñones JN, Stamilio DM, Coassolo KM, Macones GA, Odibo AO. Is fetal gender associated with adverse perinatal outcome in intrauterine growth restriction (IUGR)? Am J Obstet Gynecol. 2005;193(3):1233-7.

58. Nilima S, Sultana R, Ireen S. Neonatal, infant and under-five mortality: an application of cox proportional Hazard model to BDHS data. J Asiatic Soc Bangladesh Sci. 2018;44(1):7-14.

59. Agha S, Carton TW. Determinants of institutional delivery in rural Jhang, Pakistan. Int J Equity Health. 2011;10(1):1-12. 
60. Arunda M, Emmelin A, Asamoah BO. Effectiveness of antenatal care services in reducing neonatal mortality in Kenya: analysis of national survey data. Glob Health Action. 2017;10(1):1328796.

61. Singh A, Pallikadavath S, Ram F, Alagarajan M. Do antenatal care interventions improve neonatal survival in India? Health Policy Plan. 2014; 29(7):842-8

\section{Publisher's Note}

Springer Nature remains neutral with regard to jurisdictional claims in published maps and institutional affiliations.

Ready to submit your research? Choose BMC and benefit from:

- fast, convenient online submission

- thorough peer review by experienced researchers in your field

- rapid publication on acceptance

- support for research data, including large and complex data types

- gold Open Access which fosters wider collaboration and increased citations

- maximum visibility for your research: over $100 \mathrm{M}$ website views per year

At BMC, research is always in progress.

Learn more biomedcentral.com/submissions 